\title{
Development and evaluation of granular simulation for integrating computational thinking into computational physics courses
}

\author{
Dewi Muliyati $^{1}$ (D) Dadan Sumardani $^{2}$ (D) Siswoyo Siswoyo $^{1}$ (D) Fauzi Bakri ${ }^{1}$ (D) . \\ Handjoko Permana ${ }^{1}$ (D) Erfan Handoko ${ }^{1}$ (D) . Ni Larasati Kartika Sari ${ }^{3}$ (D)
}

Received: 1 March 2021 / Accepted: 18 August 2021 / Published online: 27 August 2021

(c) The Author(s), under exclusive licence to Springer Science+Business Media, LLC, part of Springer Nature 2021

\begin{abstract}
Computational thinking (CT) is an essential skill in the twenty-first century. The computational physics course (CPC) is one subject that is designed to support students in the practice of CT. Many studies show that the worksheets could be a solution in a CPC as a scaffold to achieve the CT objectives both online and offline. The study aims to develop the worksheet and integrate it with CT in a computational physics course. This study applied the research and development ( $R$ \& D) method with the ADDIE model approach. In the results, the evaluation test from the experts reached a very good interpretation score based on the learning media expert (96\%), the teaching material expert (95\%), and the pedagogy experts (92\%). So that this media is declared feasible to be used in the CPC. Furthermore, after the experimental study of students who took the computational physics course $(n=31)$, the study showed that the modified course could significantly improve student skills regarding overall CT ( $p$ value $<0.05$ ). However, this research also found that cooperative learning as part of CT had no improvement ( $p$ value $>0.05$ ). The experiment was conducted amid the COVID 19 pandemic wherein the students could only study at home for the whole semester. These findings indicate that the pandemic has impacted the collaborative skills of students on the course.
\end{abstract}

Keywords Granular · Physics · Computational thinking · Worksheet

\section{Introduction}

Computational thinking (CT) stands as an essential twenty-first-century skill (Guggemos, 2020; Voogt et al., 2015; Wing, 2006). CT has a vast spectrum; it has 19 capabilities that are part of CT, e.g., abstraction, algorithm design, visualization,

Dewi Muliyati

dmuliyati@unj.ac.id

Extended author information available on the last page of the article 
and problem-solving (Hsu et al., 2018). Computational physics course is one subject designed to support students to practice CT in higher education, especially in the physics department.

Universities use various methods to teach computational physics; some develop game activities in computer class to increase student motivation (Borrego et al., 2017) and use a gamification experience (Sánchez-carmona et al., 2017) or facilitate an e-Learning (Ngan \& Law, 2014). CT in learning aims to train students to be more creative and think logically (Y. Kim \& Kim, 2016). The influence of CT in education is far-reaching; many teachers are starting to include it at the level of preschool (Bers et al., 2014; Lin et al., 2020), elementary school (Chalmers, 2018; G. Chen et al., 2017; C. S. Kong \& Wang, 2020), and high school level (Guggemos, 2020; Harangus \& Kátai, 2020; Zhang \& Nouri, 2019). Many of them are even in the form of a formal curriculum that is applied in schools (Bers et al., 2014; Manson \& Olsen, 2012; Tang et al., 2020).

The computational course provides practical computation integrated into the scientific problem-solving paradigm in varied knowledge of physics, biology, algebra, and calculus (Borinskaya et al., 2013). A new physics curriculum in which computational education and practice are present would be the best general approach for physics (Landau et al., 2011). CT has important benefits for the teacher in developing ideas to face many difficulties when dealing with physics formulas (Taub et al., 2015) - for example, ranging from the quantum scale in transport phenomena simulation (Ye et al., 2021), the simulation about learning of vector fields as fundamental parts of the electrodynamics course (Budi \& Muliyati, 2018), or engineering simulations of physical phenomena (Bakri et al., 2019a), and electromotive forces in a generator (Bakri et al., 2019b). Computation in physics is important for bringing real-world problems into the classroom and making students recognize multiscale challenges (Landau et al., 2011).

According to Landau et al. (2011), students who ran computational simulations in class were probably better than just having the instructor use simulations for demonstrations; the demo method is ineffective for teaching computational physics. In a $\mathrm{CPC}$, the lecture needs to give students a solid foundation in computation and then build computational thinking.

Computational physics plays an important role as a tool to develop and understand fundamental physics and as a guide toward asking more penetrating questions (Prosperetti \& Tryggvason, 2003). To reach the stage of understanding, CT in a computational physics course requires strategies and learning media to practice these skills. Several studies using scaffolding have been shown to improve problemsolving abilities (M. C. Kim \& Hanna, 2011), collaboration (Huang et al., 2012), digital fabrication (Pitkänen et al., 2020), and computational thinking (Angeli \& Valanides, 2020; Basu et al., 2017; Gennari et al., 2016; Touretzky et al., 2013). Scaffolding is also effective in fostering students' group discourse levels and learning outcomes (Huang et al., 2012). In this research, the worksheet uses a scaffolding strategy for learning. Many research on worksheets has been developed in various fields, for example, in physics laboratories (Bakri et al., 2019c), fluid mechanics using computer simulation (Fraser et al., 2007), and simulations in the Direct Current (DC) (Mahtari et al., 2020). 
Computational contexts are efficient in physics learning (Redish \& Wilson, 1993; Taub et al., 2015). It means that programming simulations can help understand the challenging aspects of physics upon causal relationships between variables. Many simulations have been developed in physics research and education to help CT in physics courses. For example, using a computer simulation environment created in Java for the domain of linear oscillations without damping (Psycharis, 2011) and understanding the vector field using simulation in an Android application (Budi \& Muliyati, 2018). Generally, in simulation in physics, the programming process forces the students to understand the physical mechanism activating the simulation (Taub et al., 2015).

Granular is one of the fastest-growing simulations to observe microscopic scale distribution phenomena in physics, e.g., pressure (Matuttis, 1998), and macro view, e.g., waves (Muliyati et al., 2018), or powder and pores (Muliyati et al., 2019). Granular simulations can be applied to almost all physics materials, making them suitable as teaching materials for lectures in computational physics courses. Moreover, granular programming stimulates structured thinking, structured problem solving, and structured information processing (Yao, 2016). In this research. We have developed learning media in a computational physics course to integrate computational thinking skills into the classroom. This worksheet is used as a medium in the classroom using a Granular simulation system to understand computational thinking better.

\section{Literature review}

\subsection{Computational thinking}

Computational thinking takes an approach to solve problems, design systems, and understand human behavior that refers to fundamental concepts to computing (Wing, 2006). Thinking like a computer scientist means more than being able to program a computer. It requires thinking at multiple levels of abstraction (Wing, 2006).

Computational thinking promotes new ways of thinking to students across all science disciplines (Atmatzidou \& Demetriadis, 2016). This type of thinking will be part of the skillset of other scientists and everyone else. Ubiquitous computing is to today as computational thinking will be to tomorrow. Ubiquitous computing was yesterday's dream that became today's reality; computational thinking is tomorrow's reality (Wing, 2006).

The most important questions that need answering before any serious attempt can be made to introduce curricula for CT development in schools at scale. It is time to redress the gaps and broaden the twenty-first-century academic discourse on computational thinking (Grover \& Pea, 2013).

The three dimensions were content knowledge of programming, technological content knowledge of the use of block-based programming environments, and use of the environment to teach programming for CT development with appropriate contextual pedagogy (S. Kong et al., 2020). This article frames the current state of discourse on computational thinking in $\mathrm{K}-12$ education by examining mostly 
recently published academic literature using Wing's article as a springboard, identifying research gaps, and articulating priorities for future inquiries (Grover \& Pea, 2013). According to Wing (2006), computational thinking thus has the following characteristics; conceptualizing, fundamental, a way humans think complements and combines mathematical and engineering thinking, ideas, and everyone everywhere (Wing, 2006).

Computer science teaches a course called "Ways to Think Like a Computer Scientist" to college freshers, making it available to everyone, not just to computer science majors (Wing, 2006). Computational thinking has three dimensions; computational concept, computational practice, and computational practice (Lin et al., 2020; Lye et al., 2014). CT encompasses the concepts of data representation, decomposition, pattern recognition, abstraction, and algorithmic thinking. Five members of our research group independently categorized the project problems before aggregating the results. All five members were familiar with the principles of CT as well as the CS Unplugged activities used in the projects (Rodriguez et al., 2017). The CT step that would develop is shown in Table 1.

CT can be applied in different subjects across different grade levels, which brings challenges and opportunities (Tang et al., 2020). Teachers need to be systematically prepared in terms of how to design CT learning activities, how to teach CT, how to assess CT, and how to use technologies to teach CT concepts (Angeli \& Giannakos, 2020). In this research, the type of question in a worksheet based on Table 2.

Finally, we used all literature sources as the theoretical framework to develop the worksheet to train students in CT. Moreover, we considered all the theoretical frameworks obtained to build courses that had an impact on students.

\section{Methodology}

This research uses a scaffolding strategy through student worksheets to explore granular simulation in a computational physics course. The research study uses the research and development (R \& D) method through the ADDIE (Analyze, Design, Develop, Implement, and Evaluate) model approach. One of the powers of ADDIE, Davis (2013) reveals that ADDIE is one of the most recognized and used instructional system design models. Moreover, the ADDIE model is flexible enough to allow anyone to revisit a step and refine it in each five-step. For this reason, the researchers in this study used the ADDIE model as a framework for the development of student's worksheets.

Education researchers widely use research and development (R \& D) to create student worksheets, for example, for improving the students' visual-spatial intelligence and learning outcome (Gani et al., 2017), science process skill through inquiry-based learning model (Yulkifli et al., 2019), and scientific communication skills (Oktasari et al., 2019). In terms of research and development study, many models are commonly used; for example, 4D (Oktasari et al., 2019), Borg \& Gall (Khasanah et al., 2017), Dick Carey (Astra et al., 2020; Bakri et al., 2019c), and ADDIE (da Silva et al., 2016; Denny et al., 2020; Majid et al., 2015; Raihanati et al., 2017). Of the many models, the ADDIE model is the most relevant in the 


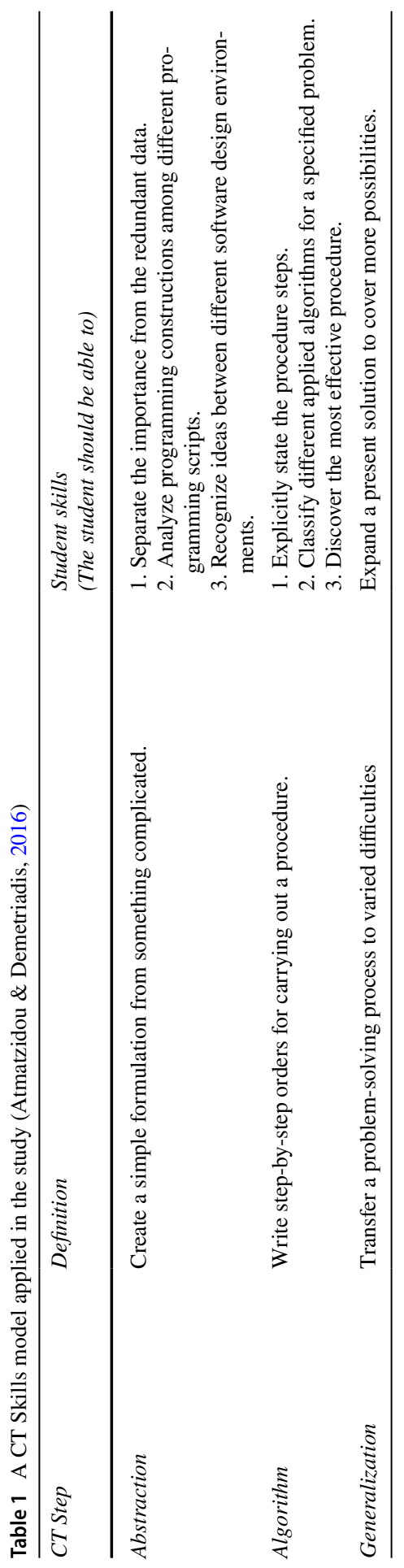


Table 2 CT skills and relevant prompts to trigger students' self-reflection (Atmatzidou \& Demetriadis, 2016)

\begin{tabular}{|c|c|}
\hline CT skills & Type of Question \\
\hline Abstraction & $\begin{array}{l}\text { How would you describe this common behavior? What is the common programming } \\
\text { structure? Which is the information you actually need? What is irrelevant detail and } \\
\text { not necessary in your description? }\end{array}$ \\
\hline Algorithm & $\begin{array}{l}\text { Write step-by-step the operations needed so that you can do what the problem asks. } \\
\text { What are the steps I will need to do to solve this problem? }\end{array}$ \\
\hline Generalization & $\begin{array}{l}\text { Propose a more general solution for the activity above that can cover a wider variety of } \\
\text { cases. Is the proposed solution more general, and why? }\end{array}$ \\
\hline
\end{tabular}

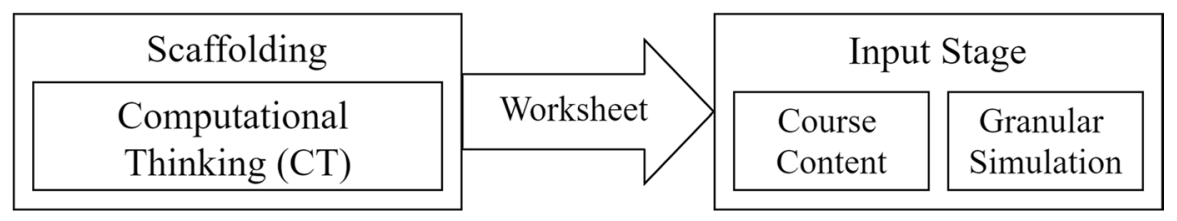

Fig. 1 Incorporating CT into a worksheet

application of this research. Many researchers apply the ADDIE model to develop Educational products such as to develop a virtual learning environment (da Silva et al., 2016), mobile learning (Shah et al., 2019; Sulisworo et al., 2016), and textbooks integrated with augmented reality (Mustami et al., 2019). The educational philosophy for this application of ADDIE is that intentional learning should be student-centered, innovative, authentic, and inspirational (Branch, 2010).

In the first phase, analysis, we conducted learning analysis in a CPC class, such as the target audience of this development (i.e., undergraduate students of physics), education objective (i.e., computational thinking), and the available resources (i.e., online learning).

In the design stage, the content was organized, and we collected analytical data and grouped the problems obtained into a flowchart. Moreover, the result of design, the CT in the CPC, needed to support using a scaffolding strategy through student's worksheet. A diagram of this concept is shown in Fig. 1.

The scaffolding strategy provides the learning framework to help the students learn the new knowledge (Hsu et al., 2018). The purpose of scaffolding is to train the students to solve problems independently (Hsu et al., 2018). Researchers emphasize the importance of providing additional support or scaffolding to facilitate learners' cognitive development during the learning process (W. Chen et al., 2010; Huang et al., 2012; Wood et al., 1976). Korkmaz et al. (2017) said that computational thinking covers the skills of critical thinking, creativity, cooperativity, algorithmic thinking, and problem-solving. In this research, the worksheet uses three steps of CT: abstracting, algorithm, and generalizing. The diagram about an illustration of worksheet design is shown in Fig. 2. 


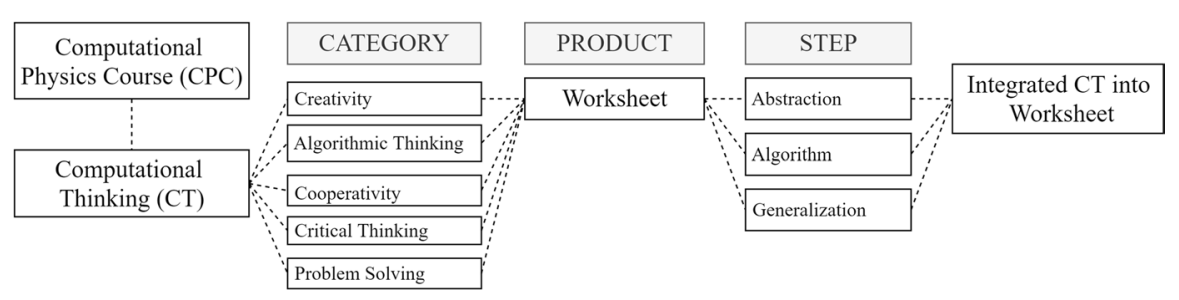

Fig. 2 Schematic illustration of worksheet design

The researcher decided to use three dimensions of CT in developing a worksheet as scaffolding in the computational course and five categories of CT provided in the step of the worksheet. The result of this development is the integrated CT in a worksheet in the computational physics course.

In the development stage, we created simulations using Unity3D and involved programming using Visual Studio 2017. Google Drive was also used to store the executable simulation for Windows 10; then, students can download it via a browser at https://osf.io/wcyqn/.

In the implementation stage, the pre- and post-test ${ }^{1}$ using Google Form were made available on an educational platform, allowing access through the internet. The student's worksheet can be accessed from our data repository at https://osf.io/ 5tehf/.

The evaluation of the student's worksheet was carried out by three experts with experience in learning media, teaching material, and pedagogy to verify the adequacy of the content and strategies used for the learning process of the target audience.

After developing the learning media, we implemented the worksheet in a case experiment study. This case experiment uses a quasi-experimental design with a pretest and post-test approach. The respondents consisted of undergraduate students in physics at the State University of Jakarta (Universitas Negeri Jakarta) who attended the computational physics course. Based on the survey, it was found that there were only 62 students registered for the subject during the course of study, consisting of a physics education class $(n=31)$ and a physics class $(n=34)$. We decided to use the former class as an experiment class and the latter as a class to test the reliability of the questionnaire item. All participants in the research were purely voluntary and understood how they were to be engaged. The participants' data was anonymized and kept confidential in the research.

The questionnaire to measure CT skills used in this study was adapted from the questionnaire designed by Korkmaz et al. (2017). The questionnaire served as an instrument to obtain CT scores before and after intervention consisting of creativity, algorithmic thinking, cooperativity, critical thinking, and problem-solving. Fivepoint Likert was used in the expert evaluation and CT scale. The scale ranges from strongly disagrees (1), disagree (2), neutral (3), agree (4), and strongly agree (5).

\footnotetext{
${ }^{1}$ https://s.id/ct-posttest
} 


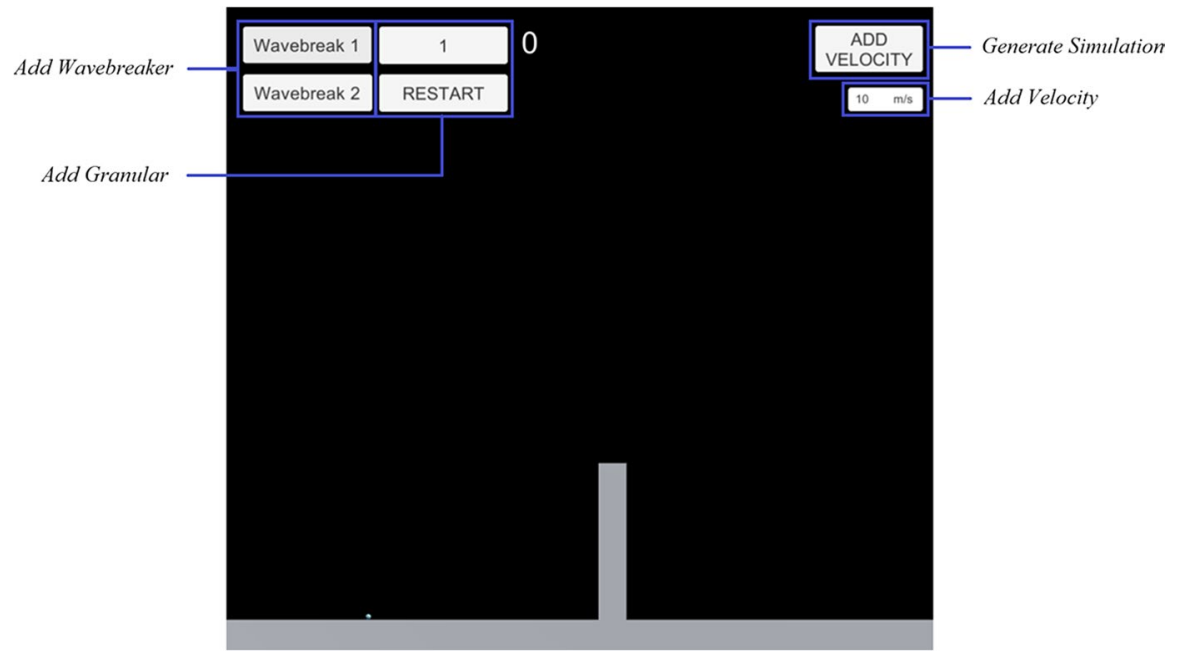

Fig. 3 The Component of Simulation

\section{Result and discussion}

\subsection{Application}

Applications were created using the Unity3D application and Visual Studio 2017 coded in $\mathrm{C \#}$ applications made to follow the three golden rules to design User Interface (UI) that consist of user control, memory load, and consistency (Bahrami \& Bahrami, 2012). This application also uses an interactive interface to motivate the student (Malkawi et al., 2019). Technically, there are various buttons that users could press to activate certain functions, such as the Wavebreak button (Fig. 3) to bring up a wall for breaking waves.

In this study, three simulations were used, namely Wavebreaker Simulation, simulation of granular adhesion to horizontal porous skin, and simulation of granular adhesion to vertical porous skin. The three simulation applications can be seen in Table 3 .

Three applications were used on students with different learning objectives. In the three applications, the general objective is to develop CT in students in formulating a problem and its solutions so that humans and machines can effectively carry it out (Lei et al., 2020; Wing, 2006). Students were also encouraged to describe and organize data with appropriate graphs, charts, words, or images as part of CT (Hsu et al., 2018). For example, the resulting process in the Wavebreak Simulation was observed in increasing a given velocity that affects the reached maximum height particle and convergence of the granular particle movement (Muliyati et al., 2018). In addition, learning aims to describe the complex problems of the application into a description in the form of algorithmic notions of the flow of control (Grover \& Pea, 2013). 
Table 3 The simulation that used in this study.

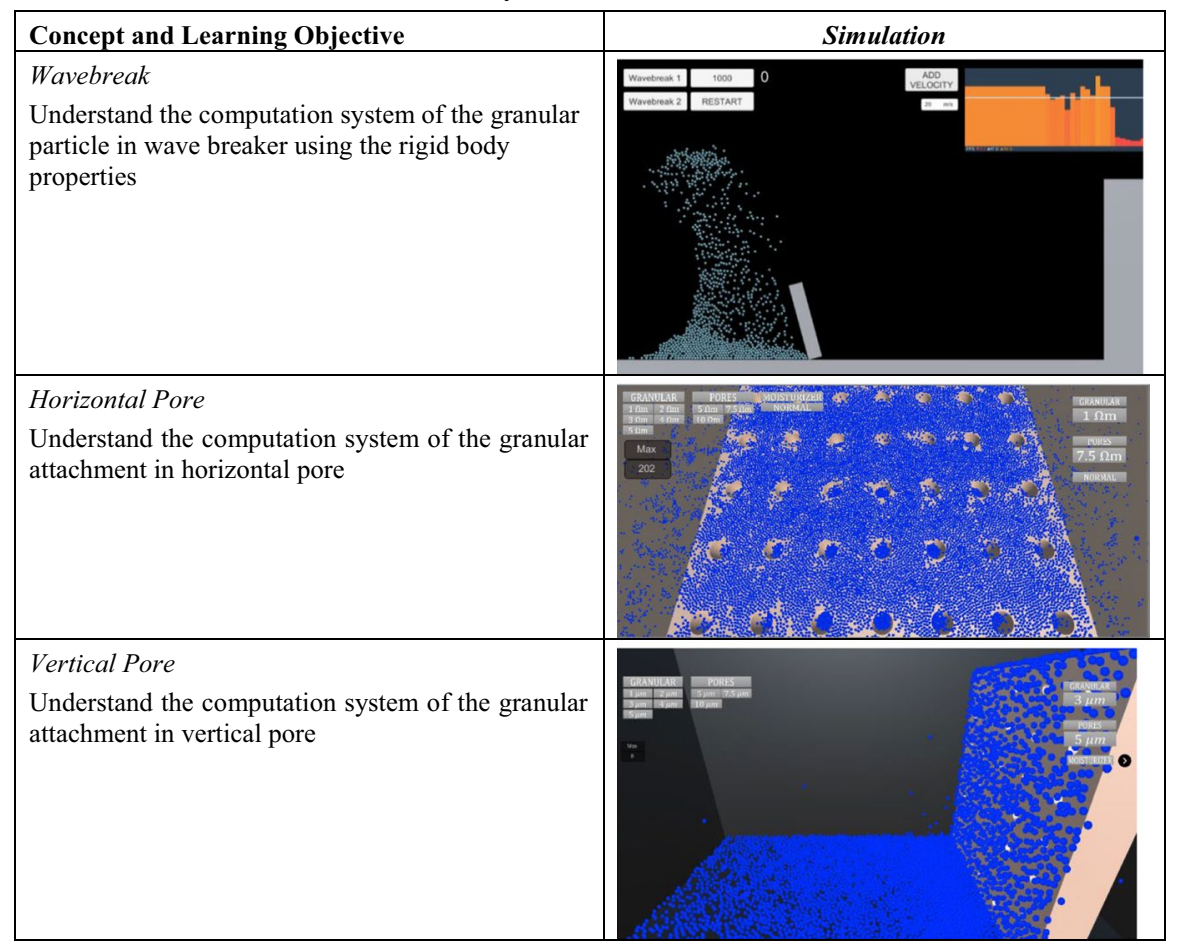

\subsection{Student learning outcomes after using the application}

Learning outcomes are important to monitor and to aid good teaching and learning. Learning outcomes are useful as practical tools in teaching and learning activities and in designing study programs (Hussey \& Smith, 2010). The learning outcomes can be seen in Table 4.

\subsection{Worksheet}

Many studies using scaffolding show an improvement in problem-solving abilities (M. C. Kim \& Hanna, 2011), collaborative behaviors (Huang et al., 2012), digital fabrication (Pitkänen et al., 2020), and computational thinking (Angeli \& Valanides, 2020; Basu et al., 2017; Gennari et al., 2016; Touretzky et al., 2013). Scaffolding is effective in fostering students' group discourse levels and learning outcomes (Huang et al., 2012). Learning practicum using the worksheet as a scaffold also provides students opportunities to find and apply concepts (Bakri et al., 2020). In this research, the worksheet was applied as a scaffolding strategy in the CPC. CT has three dimensions (Lin et al., 2020; Lye et al., 2014), and every dimension was added to every step of the worksheet. The steps of the worksheet are shown in Figs. 4, 5, 6, 7 and 8. 
Table 4 Teaching and learning process.

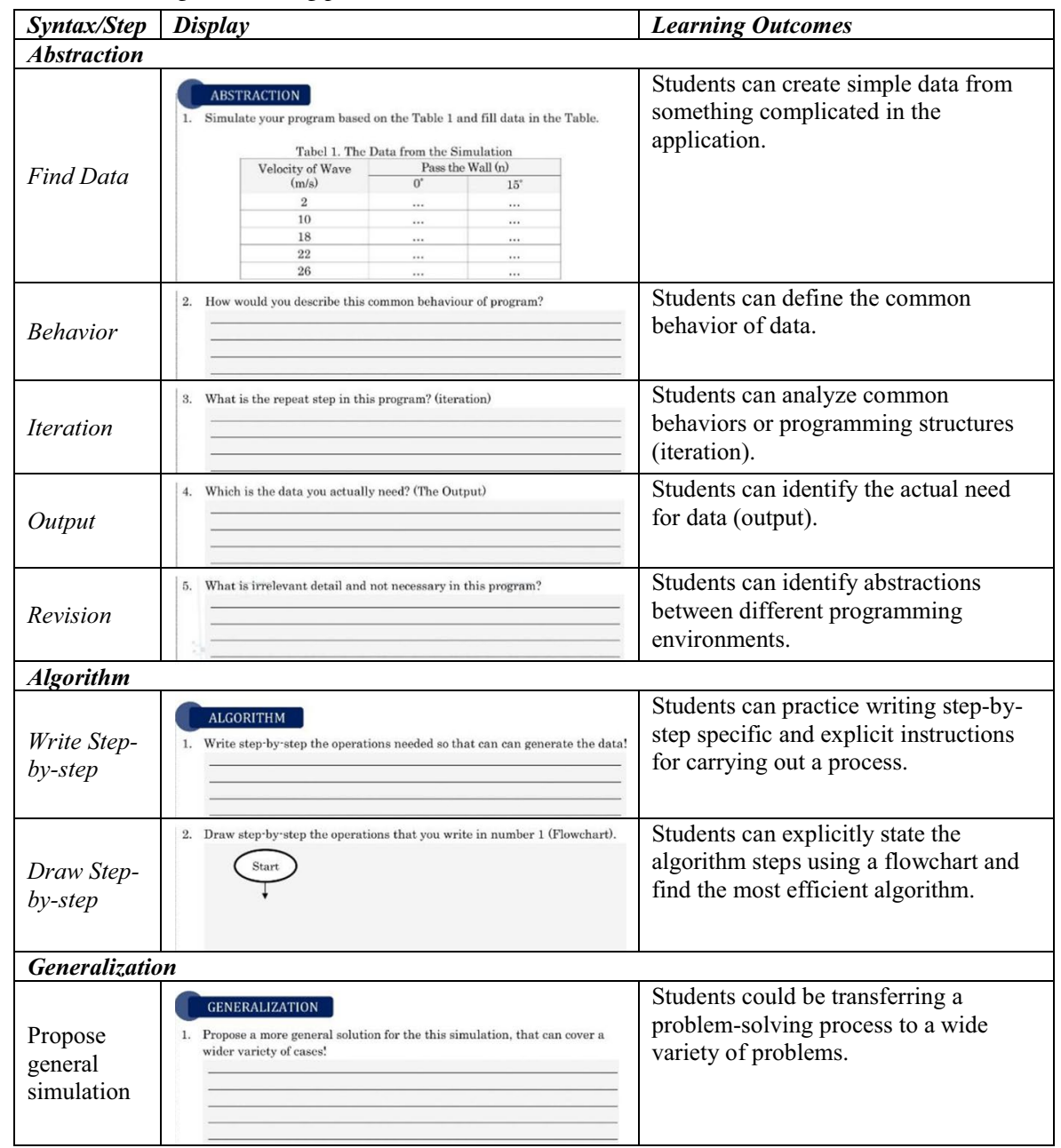

The cover (Fig. 4), the first page of worksheet, provides the learning objectives. It is important to identify objectives in the classroom for learners to achieve to stimulate and excite attention (Waiyakoon et al., 2015).

The procedure in the worksheet stage is needed to invite students to understand what to do (Fig. 5). Some lecturers give this stage verbally, although, to support independent learning, worksheets can be added with procedures (Bakri et al., 2020).

Abstracting is a stage for practicing CT (Barr \& Stephenson, 2011; Grover \& Pea, 2013). This section describes the simulation and process in the system (Fig. 6). Abstraction is the process of creating something simple from something complicated (Atmatzidou \& Demetriadis, 2016). In this step, students learned about fundamental programming concepts such as sequences and looping (iteration) as part of computational concepts (Lin et al., 2020; Lye et al., 2014). This step aimed to separate the 
Fig. 4 The Purpose page

Computational Physics

\section{WAVEBREAKER}

Simulation of Granular in Two Dimensions

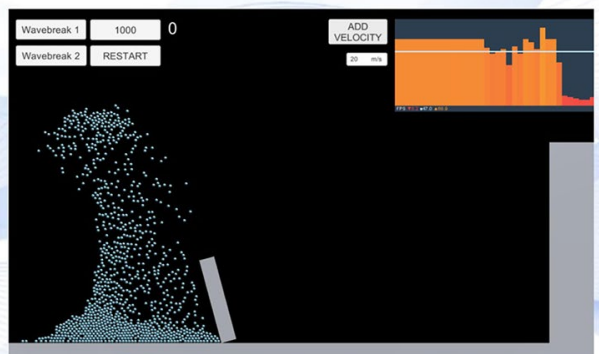

Figure 1. Wavebreak Simulation

\section{PURPOSE}

1. Understand the computation system of the granular particle in wave breaker using the rigid body properties.

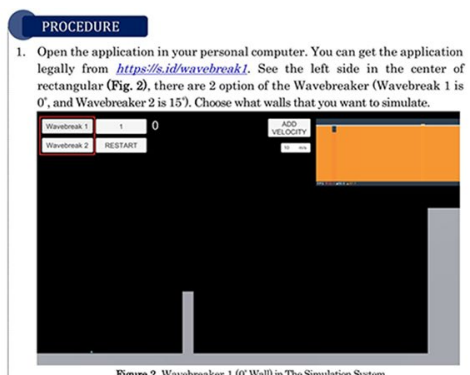

2. When you finally choose the type of walls, the next step is select the number of granular $(n=1000)$ that you want to simulate. And if you want to restart

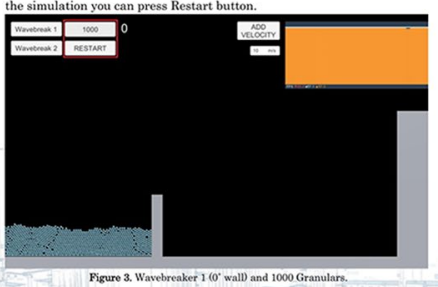

Figure 3. Wavebreaker $1 .\left(0^{\circ}\right.$ wall and 1000 Granulars.

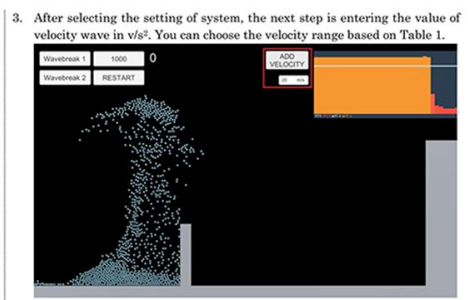

Figure 4. Wavebreaker $1\left(0^{\prime}\right.$ walli, 1000 Grimulars and $20 \mathrm{~m} / \mathrm{s}$ of velocity.

4. Finally, you can count how many granular that pass the wall in several setting. Fill your simulation data in Table 1.

Fig. 5 Procedure in the worksheet 


\section{ABSTRACTION}

1. Simulate your program based on the Table 1 and fill data in the Table.

Tabel 1. The Data from the Simulation

\begin{tabular}{|c|c|c|}
\hline \multirow{2}{*}{$\begin{array}{c}\text { Velocity of Wave } \\
(\mathrm{m} / \mathrm{s})\end{array}$} & \multicolumn{2}{|c|}{ Pass the Wall (n) } \\
\cline { 2 - 3 } & $0^{\circ}$ & $15^{\circ}$ \\
\hline 2 & $\ldots$ & $\ldots$ \\
\hline 10 & $\ldots$ & $\ldots$ \\
\hline 18 & $\ldots$ & $\ldots$ \\
\hline 22 & $\ldots$ & $\ldots$ \\
\hline 26 & $\ldots$ & $\ldots$ \\
\hline
\end{tabular}

2. How would you describe this common behaviour of program?

3. What is the repeat step in this program? (iteration)

4. Which is the data you actually need? (The Output)

5. What is irrelevant detail and not necessary in this program?

Fig. 6 Abstraction step

important from the redundant information, to analyze and specify common behaviors or programming structures between different scripts, and identify abstractions between different programming environments (Atmatzidou \& Demetriadis, 2016). This section also includes data collection, data analysis, data representation, and problem decomposition (Y. Kim \& Kim, 2016).

At the algorithm stage (Fig. 7), students were given analysis and the stages of drawing a flowchart. Flowcharts are important in shaping CT and triggering students to understand more deeply about how computers work (Barr \& Stephenson, 2011; Grover \& Pea, 2013; Hsu et al., 2018). The algorithm in this step is a practice of writing step-by-step specific and explicit instructions for carrying out a process 


\section{ALGORITHM}

1. Write step-by-step the operations needed so that can can generate the data!

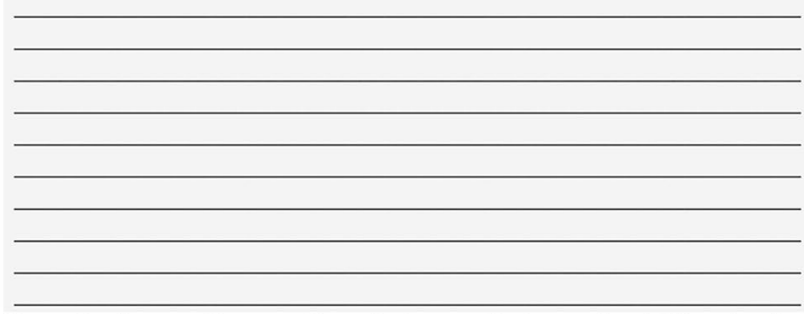

2. Draw step-by-step the operations that you write in number 1 (Flowchart).

Start

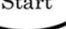

7

Fig. 7 Algorithm Step

(Atmatzidou \& Demetriadis, 2016). The algorithm step aims to explicitly state the algorithm steps, to identify different effective algorithms for a given problem, and to find the most efficient algorithm. In this step, students learn about problem-solving skills such as testing and debugging as part of computational practices (Lin et al., 2020; Lye et al., 2014).

In the generalization stage (Fig. 8), students are encouraged to recognize ideas and apply them in other fields; students can interpolate their ideas into various fields that they work on. This worksheet explains wave breakers, and students can find out for themselves what programs can be developed using a 


\section{GENERALIZATION}

1. Propose a more general solution for the this simulation, that can cover a wider variety of cases!

2. Is the proposed solution in point 1 is more general ? Why?

Fig. 8 Generalization Step

$\mathrm{CT}$ framework. The generalization is transferring a problem-solving process to a wide variety of problems, expanding an existing solution in a given problem to cover more cases (Atmatzidou \& Demetriadis, 2016). In case of questioning, the use of technology is part of computational perspectives. It means that students understand the relationships between themselves and others in a technological context (Lin et al., 2020; Lye et al., 2014). 
Table 5 The validation results of the students' worksheet

\begin{tabular}{llll}
\hline No. & Aspects Measured & Presentation Score & Interpretation \\
\hline Learning Media Validation & & & \\
1 & Worksheet Component & $95 \%$ & Very Good \\
2 & Typography of contents & $97 \%$ & Very Good \\
Average of all aspects & & $\mathbf{9 6 \%}$ & Very Good \\
Teaching Material Validation & & & \\
1 & Material content & $97 \%$ & Very Good \\
2 & Writing Language & $93 \%$ & Very Good \\
Average of all aspects & & $\mathbf{9 5 \%}$ & Very Good \\
Pedagogy Expert Validation & & & \\
1 & Didactic aspect & $90 \%$ & Very Good \\
2 & Construction aspect & $98 \%$ & Very Good \\
3 & CT in Worksheet & $93 \%$ & Very Good \\
4 & Characteristics of CT & $98 \%$ & Very Good \\
5 & Abstraction & $88 \%$ & Very Good \\
6 & Algorithmic Thinking & $87 \%$ & Very Good \\
7 & Generalization & $90 \%$ & Very Good \\
Average of all aspects & & $\mathbf{9 2 \%}$ & Very Good \\
\hline
\end{tabular}

\subsection{Evaluation test}

The fifth stage of the ADDIE model is evaluation. The evaluation test used Likert as a sample of evaluation tools (Branch, 2010). The evaluation of the student's worksheet was carried out by three experts with experience in learning media, teaching material, and pedagogy. In the process of evaluation framework, the experts including lecture and schoolteacher who specialize in the study were invited to review and evaluate the model, thus raising the validity of the product. The evaluation results are shown in Table 5.

The results of media validation have obtained very good interpretation (overall $96 \%$ ). It means that the worksheet component (95\%) and typography of contents (97\%) were deemed appropriate by experts. The results of the material validation were obtained excellent interpretation (overall 95\%). The material presented logical principles in the worksheet in Granular content. From material experts, good material content is gained (97\%), and suitable in writing language (93\%), e.g., it was easy for the student to know meanings and prevent misconceptions.

The results of learning validation have an average score of $92 \%$. Each component of learning expert validation is suitable in the didactic aspect (90\%), e.g., emphasizes students on the process of learning concepts, contains contextual learning, construction aspect (98\%), e.g., provide sufficient space to provide flexibility for students to write down their observations on a worksheet, CT in the worksheet (93\%), e.g., potentially approach to solving problems, and to understand human behavior, characteristics of CT (98\%), e.g., provide a way that humans think, and potentially can develop CT, abstraction (88\%), e.g., trigger student to create something simple 
Table 6 The grouping of the questionnaire items

\begin{tabular}{ll}
\hline Category & Questionnaire Items \\
\hline 1. Creativity & $20,21,22,23,24,25,27,28$ \\
2. Algorithmic Thinking & $1,5,6,7,8,9$ \\
3. Cooperativity & $14,15,16,17$ \\
4. Critical Thinking & $10,11,12,13,29$ \\
5. Problem Solving & $2,3,4,18,19,26$ \\
\hline
\end{tabular}

from something complicated, separate, and identify abstractions between different programming environments, algorithmic thinking (87\%) i.e., trigger student to practice writing step-by-step, and find the most efficient algorithm, generalization (90\%) i.e., trigger student to transferring a problem-solving process, expand more possibilities. In learning expert perception, the critical step in a worksheet to train CT, abstraction, algorithmic thinking, and generalization have shown good interpretation, meaning this worksheet potentially allows students to improve their skills.

\subsection{The validity and the reliability}

After the media was developed and evaluated, it was tested on classroom activity using a questionnaire developed by Korkmaz et al. (2017) and detailed in Appendix Table 8, to check the students' CT skills before and after the intervention. The validity tests were conducted to test the construct validity of the CT test; the results have been determined as valid using Kaiser-Meyer-Oklin $(\mathrm{KMO})=0.914$ and the Bartlett test value $x^{2}=15,886.208$ (Korkmaz et al., 2017).

In this research, most of the categories in the questionnaire reach high reliability, but for item 24, reliability was very low; therefore, this item questionnaire was omitted (see Appendix Table 9). After reorganizing, all categories resulted in high reliability (Cronbach's alpha was 0.876 for all categories). In addition, the reliability test using alpha Cronbach in previous research was reliable (Cronbach's alpha 0.822 for all categories) (Korkmaz et al., 2017). The grouping of the questionnaire statements is shown in Table 6.

\subsection{Data analysis of student response}

In this work, after reorganization based on validity and reliability, we used the questionnaire to analyze student responses via CT. All respondents for this study pursued an undergraduate degree in a computational physics course at the physics department, State University of Jakarta. The data collection was conducted with pre-test and post-test for computational thinking. The questionnaire was used to determine the response of students after using students' worksheets. The data were organized using the spreadsheet in Microsoft Excel 365 and SPSS software.

The intervention consisted of several stages; students used worksheets independently for three topics. The collected data then presented in a paired t-test to see the significance of the intervention (see Appendix Table 10). For data collection, 
Table 7 The experimental group results (Physics Education Class)

\begin{tabular}{llllll}
\hline$N=31$ & $\begin{array}{l}\text { Average score } \\
\text { (pre-test) }\end{array}$ & $\begin{array}{l}\text { Averagescore } \\
\text { (post-test) }\end{array}$ & $\begin{array}{l}\text { Difference } \\
\text { average } \\
\text { (pre-test) }\end{array}$ & $\begin{array}{l}\text { Difference } \\
\text { average } \\
\text { (post-test) }\end{array}$ & $\begin{array}{l}\text { Paired t-test } \\
\text { Significance }\end{array}$ \\
\hline Category & & & & \\
Entire Questionnaire & 68.69 & 70.51 & 5.47 & 5.23 & $P=0.045$ \\
Creativity & 72.47 & 74.96 & 6.83 & 7.45 & $P=0.041$ \\
Algorithmic Thinking & 61.39 & 65.69 & 9.73 & 8.70 & $P=0.014$ \\
Cooperativity & 83.54 & 80.81 & 12.79 & 14.03 & $P=0.127$ \\
Critical Thinking & 66.45 & 68.64 & 8.49 & 7.45 & $P=0.045$ \\
Problem Solving & 64.09 & 66.88 & 6.70 & 7.29 & $P=0.047$ \\
\hline
\end{tabular}

29 main instruments were used in a Likert-type questionnaire. First, the questionnaire was given to students before the intervention as a preliminary test; then, we organized the questionnaire items by category and calculated the average score of all statements in each category for each student. Second, we calculated the average scores of all students for the entire questionnaire. When statistical differences from the pre-test scores between the two situations were found. Finally, we conducted paired t-tests, comparing the mean scores of all students across the questionnaire and each category separately, pre-test and post-test. The paired t-test was used to determine whether the experimental class acquired a higher ability after the intervention.

Table 7 shows that in the experimental group, after the intervention, the statistical analysis of the whole category was significant $(P=0.045)$ and marked improvement $(P<0.05)$ in students' computational thinking, according to all questionnaires and overall categories, except for the cooperativity category. However, in one category, the cooperative category, there was an anomaly where a high a priori score became a low score in the final session.

From Table 7 , creativity category was a significant $(P=0.041)$ and marked improvement $(P<0.05)$. This category shows that student skills had significant improvement using the learning media, such as trusting their intuition and feelings of "trueness" and "wrongness" when they approach a problem and the belief that they can solve any problems when they encounter a new situation. This condition was supported by the experiment from Dinica et al. (2010) that such experiments in physics using interactive strategies lead to the students' creativity development.

In the algorithmic thinking category, student skill also significantly improved $(P=0.014 ; P<0.05)$, the student improvement. This condition is the same as the previous research results that reveal the optimal educational method of developing students' algorithmic thinking is the system and multidisciplinary approach based on the identification of real systems, processes, and modelling (Hubalovsky, 2015).

In critical thinking, the improvement of skill was significant $(P=0.045, P<0.05)$. This category included the willingness to learn challenging activities, feeling eager to solve complex problems, and using a systematic method when comparing the options while reaching a decision. In this limited condition, critical thinking could 
still improve. Based on the research from Hussin et al. (2019), critical thinking can be improved either online learning or offline learning; the keyword is interaction. Then, Bakri et al. (2018) and Denny et al. (2020) also reveal that critical thinking can be reached using e-learning or blended learning (Tab 10).

In the problem-solving category, there was a significant $(P=0.045 ; P<0.05)$ and marked improvement. This category included applying the solution that students plan, demonstrating the solution of a problem, developing their ideas in the environment, and producing so many options while thinking of the possible solution to a problem. In this study, we tried to support students in generalizing the theory from the learning process to other fields. Innovative learning is needed to improve problem-solving abilities in overcoming students' physics problems (Tumanggor et al., 2019).

In the cooperativity category, there was an anomaly where a high a priori score (83.54) became a low score in the final session (average score $=80.81$ ). Because of the decrease of score, the paired t-test (average score $=0.127$ ) was not significant $(p>0.05)$. The items that have not increased include solving problems related to a group project and friends, experiencing cooperative learning together, encouraging ideas in cooperative learning, and attaining successful results in a working group. To explain, this may partly be due to the pandemic, and reliance on independent learning may have placed a burden on cooperative learning skills. From a recent study by Ivone et al. (2020), the previous research reveals to use almost no cooperative learning. Thus, even without the financial and technological obstacles, cooperative learning may not be applied in pandemic conditions. Moreover, the previous research from Farn-Shing Chen et al. (2020) reveals that different cooperative learning methods had significant differences in their achievement in programming design learning. Face-to-face learning was superior to online learning in pandemic situations because of more learning difficulties and problems (F. S. Chen et al., 2020). These findings could become further research related to cooperative approaches in learning topics such as physics and computation in various learning conditions.

\section{Conclusions}

The worksheet in the computational physics course has been developed in this research. The expert evaluation results inform that the worksheet of computational thinking has met the criteria in terms of teaching material, learning media, and pedagogy so that it is declared very feasible to be used within the computational physics course. Moreover, after the experimental study of students who took the computational physics course $(n=31)$, the results show that the modified course significantly improved student skills regarding overall CT $(p<0.05)$. However, this research also found that cooperative learning as part of $\mathrm{CT}$ in the experiment condition had no improvement $(p>0.05)$. Moreover, the experiment was conducted amid the COVID 19 pandemic wherein the students could only study at home during the semester. This finding indicates that the pandemic has had an impact on collaborative skills in students on the CPC. 


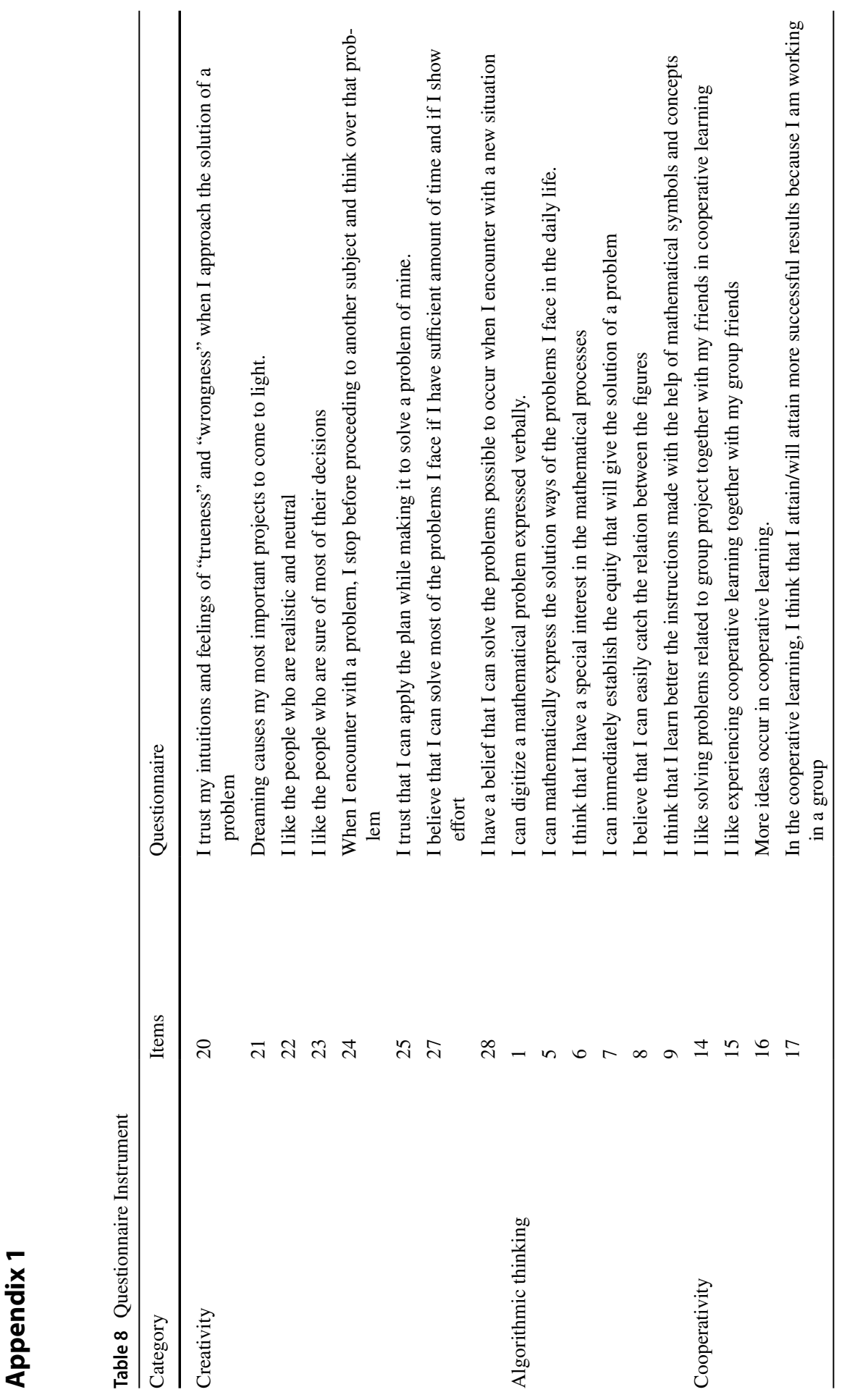




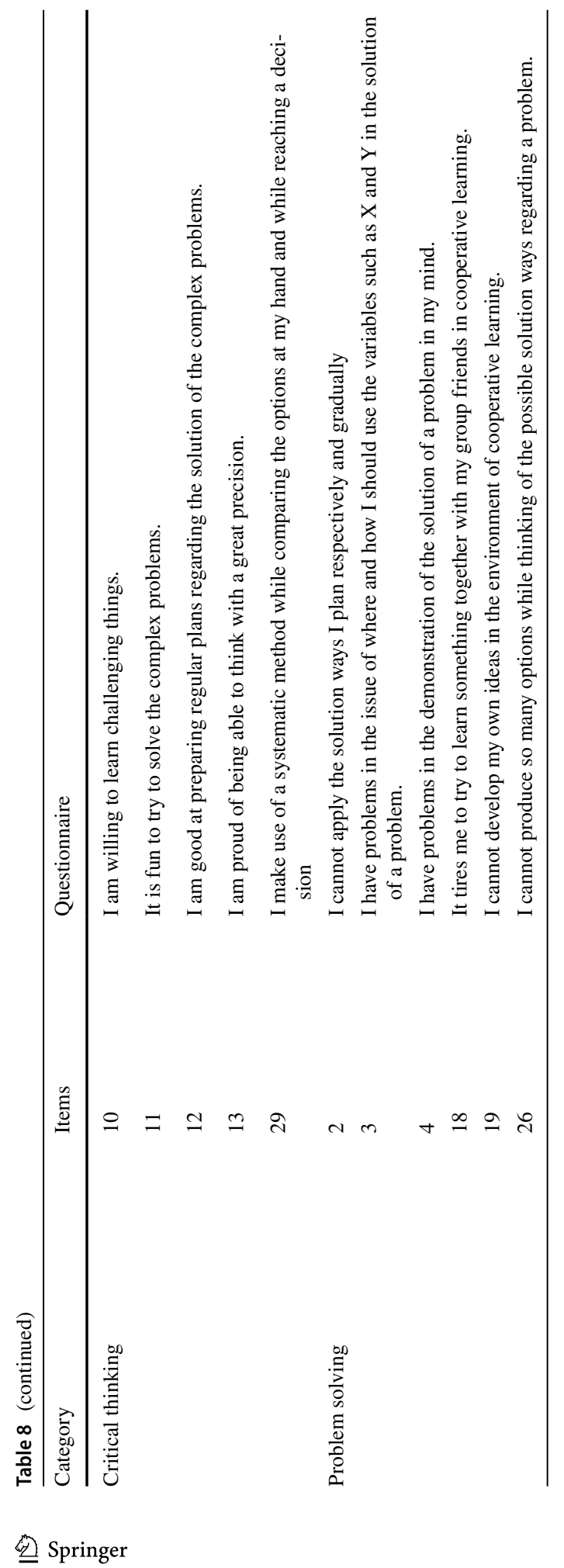




\section{Appendix 2}

Table 9 The Reliability of Questionnaire

\begin{tabular}{|c|c|c|c|c|}
\hline Item & $\begin{array}{l}\text { Scale Mean if Item } \\
\text { Deleted }\end{array}$ & $\begin{array}{l}\text { Scale Variance if Item } \\
\text { Deleted }\end{array}$ & $\begin{array}{l}\text { Corrected Item-Total } \\
\text { Correlation }\end{array}$ & $\begin{array}{l}\text { Cronbach's } \\
\text { Alpha if Item } \\
\text { Deleted }\end{array}$ \\
\hline 1 & 102.1290 & 115.516 & .125 & .855 \\
\hline 2 & 101.9355 & 112.129 & .237 & .854 \\
\hline 3 & 102.0000 & 111.933 & .223 & .854 \\
\hline 4 & 102.1935 & 108.295 & .333 & .852 \\
\hline 5 & 101.9032 & 109.090 & .419 & .849 \\
\hline 6 & 101.9032 & 102.624 & .589 & .842 \\
\hline 7 & 102.0968 & 106.624 & .487 & .846 \\
\hline 8 & 101.9355 & 112.529 & .213 & .854 \\
\hline 9 & 101.6129 & 107.778 & .496 & .846 \\
\hline 10 & 101.5806 & 106.118 & .546 & .845 \\
\hline 11 & 101.6774 & 106.026 & .590 & .844 \\
\hline 12 & 102.0323 & 111.032 & .391 & .850 \\
\hline 13 & 101.4839 & 105.858 & .623 & .843 \\
\hline 14 & 101.5161 & 103.858 & .609 & .842 \\
\hline 15 & 101.3871 & 104.578 & .715 & .840 \\
\hline 16 & 101.4194 & 104.452 & .607 & .842 \\
\hline 17 & 101.3871 & 105.445 & .623 & .843 \\
\hline 18 & 101.7419 & 109.398 & .327 & .852 \\
\hline 19 & 101.5806 & 109.585 & .392 & .849 \\
\hline 20 & 101.9355 & 109.796 & .305 & .852 \\
\hline 21 & 101.5806 & 112.452 & .205 & .855 \\
\hline 22 & 100.9677 & 108.966 & .459 & .848 \\
\hline 23 & 100.9677 & 110.632 & .378 & .850 \\
\hline 24 & 103.0645 & 127.262 & $-.573 * *$ & $.876^{* *}$ \\
\hline 25 & 101.5806 & 109.385 & .463 & .848 \\
\hline 26 & 102.3871 & 115.978 & .018 & .859 \\
\hline 27 & 101.1290 & 114.316 & .131 & .856 \\
\hline 28 & 101.2903 & 105.346 & .614 & .843 \\
\hline 29 & 101.5161 & 108.058 & .475 & .847 \\
\hline
\end{tabular}

**Delete due to the low reliable 


\section{Appendix 3}

Table 10 Score of Experimental Group (Physics Education) $(N=31)$

\begin{tabular}{|c|c|c|c|c|c|c|c|c|c|c|c|c|}
\hline \multirow[t]{2}{*}{ ID } & \multicolumn{2}{|c|}{ Overall } & \multicolumn{2}{|c|}{ Creativity } & \multicolumn{2}{|c|}{$\begin{array}{l}\text { Algorithmic } \\
\text { Thinking }\end{array}$} & \multicolumn{2}{|c|}{ Cooperativity } & \multicolumn{2}{|c|}{$\begin{array}{l}\text { Critical } \\
\text { Thinking }\end{array}$} & \multicolumn{2}{|c|}{$\begin{array}{l}\text { Problem } \\
\text { Solving }\end{array}$} \\
\hline & Pre & Post & Pre & Post & Pre & Post & Pre & Post & Pre & Post & Pre & Post \\
\hline 1 & 65.93 & 78.52 & 73.33 & 80.00 & 50.00 & 80.00 & 80.00 & 80.00 & 72.00 & 80.00 & 60.00 & 73.33 \\
\hline 2 & 69.63 & 68.89 & 73.33 & 76.67 & 56.67 & 60.00 & 100.00 & 90.00 & 64.00 & 64.00 & 63.33 & 60.00 \\
\hline 3 & 76.30 & 78.52 & 80.00 & 80.00 & 73.33 & 80.00 & 80.00 & 80.00 & 80.00 & 80.00 & 70.00 & 73.33 \\
\hline 4 & 69.63 & 74.07 & 66.67 & 63.33 & 60.00 & 66.67 & 100.00 & 100.00 & 68.00 & 72.00 & 63.33 & 76.67 \\
\hline 5 & 70.37 & 78.52 & 70.00 & 80.00 & 60.00 & 70.00 & 100.00 & 100.00 & 68.00 & 64.00 & 63.33 & 83.33 \\
\hline 6 & 65.93 & 64.44 & 60.00 & 60.00 & 53.33 & 60.00 & 100.00 & 80.00 & 60.00 & 56.00 & 66.67 & 70.00 \\
\hline 7 & 64.44 & 65.93 & 73.33 & 63.33 & 50.00 & 60.00 & 85.00 & 75.00 & 68.00 & 64.00 & 60.00 & 56.67 \\
\hline 8 & 70.37 & 74.81 & 83.33 & 90.00 & 70.00 & 80.00 & 75.00 & 80.00 & 60.00 & 68.00 & 60.00 & 66.67 \\
\hline 9 & 66.67 & 65.19 & 73.33 & 70.00 & 56.67 & 53.33 & 65.00 & 65.00 & 60.00 & 60.00 & 63.33 & 63.33 \\
\hline 10 & 65.93 & 64.44 & 63.33 & 73.33 & 50.00 & 70.00 & 80.00 & 75.00 & 68.00 & 68.00 & 63.33 & 60.00 \\
\hline 11 & 62.22 & 71.85 & 83.33 & 86.67 & 60.00 & 60.00 & 85.00 & 85.00 & 68.00 & .00 & 56.67 & 60.00 \\
\hline 12 & 69.63 & 69.63 & 83.33 & 76.67 & 66.67 & 70.00 & 85.00 & 80.00 & 52.00 & 72.00 & 66.67 & 63.33 \\
\hline 13 & 77.78 & 74.07 & 66.67 & 80.00 & 46.67 & 60.00 & 100.00 & 95.00 & 72.00 & 68.00 & 33 & 56.67 \\
\hline 14 & 60.00 & 69.63 & 60.00 & 63.33 & 60.00 & 53.33 & 70.00 & 85.00 & 80.00 & 76.00 & 66.67 & 60.00 \\
\hline 15 & 58.52 & 57.04 & 73.33 & 80.00 & 73.33 & 63.33 & 55.00 & 65.00 & 60.00 & 72.00 & 0 & 56.67 \\
\hline 16 & 71.85 & 69.63 & 73.33 & 80.00 & 60.00 & 63.33 & 90.00 & 85.00 & 48.00 & 52.00 & 56.67 & 56.67 \\
\hline 17 & 66.67 & 63.70 & 63.33 & 73.33 & 86.67 & 76.67 & 100.00 & 85.00 & 72.00 & 68.00 & 66.67 & 63.33 \\
\hline 18 & 78.52 & 81 & 00 & 70.00 & 33 & 60.00 & 95.00 & 95.00 & 64.00 & 60.00 & 70.00 & 63.33 \\
\hline 19 & 68.89 & 71.11 & 73.33 & 76.67 & 73.33 & 76.67 & 80.00 & 65.00 & 80.00 & 80.00 & 66.67 & 63.33 \\
\hline 20 & 77.04 & 72.59 & 80.00 & 73.33 & 66.67 & 70.00 & 95.00 & 85.00 & 68.00 & 76.00 & 56.67 & 63.33 \\
\hline 21 & 74.07 & 71.11 & 66.67 & 73.33 & 63.33 & 66.67 & 80.00 & 60.00 & 76.00 & 76.00 & 70.00 & 70.00 \\
\hline 22 & 66.67 & 67.41 & 80.00 & 86.67 & 70.00 & 83.33 & 75.00 & 70.00 & 56.00 & 64.00 & 63.33 & 73.33 \\
\hline 23 & 71.85 & 79.26 & 80.00 & 83.33 & 66.67 & 66.67 & 85.00 & 80.00 & 72.00 & 80.00 & 73.33 & 66.67 \\
\hline 24 & 75.56 & 74.07 & 70.00 & 66.67 & 50.00 & 53.33 & 80.00 & 80.00 & 76.00 & 76.00 & 60.00 & 70.00 \\
\hline 25 & 62.96 & 65.93 & 63.33 & 76.67 & 53.33 & 73.33 & 85.00 & 85.00 & 60.00 & 64.00 & 50.00 & 70.00 \\
\hline 26 & 59.26 & 72.59 & 66.67 & 76.67 & 70.00 & 63.33 & 80.00 & 100.00 & 52.00 & 60.00 & 63.33 & 70.00 \\
\hline 27 & 68.15 & 68.89 & 80.00 & 76.67 & 73.33 & 66.67 & 85.00 & 100.00 & 68.00 & 64.00 & 66.67 & 66.67 \\
\hline 28 & 74.07 & 73.33 & 76.67 & 66.67 & 70.00 & 60.00 & 60.00 & 60.00 & 76.00 & 72.00 & 83.33 & 76.67 \\
\hline 29 & 62.96 & 65.93 & 70.00 & 66.67 & 50.00 & 53.33 & 80.00 & 80.00 & 60.00 & 64.00 & 60.00 & 70.00 \\
\hline 30 & 65.19 & 65.19 & 76.67 & 80.00 & 50.00 & 56.67 & 60.00 & 40.00 & 72.00 & 76.00 & 66.67 & 66.67 \\
\hline 31 & 72.59 & 74.81 & 73.33 & 73.33 & 60.00 & 60.00 & 100.00 & 100.00 & 60.00 & 64.00 & 76.67 & 83.33 \\
\hline
\end{tabular}


Funding We gratefully acknowledge support from the Hibah Penelitian Unggulan Universitas - Universitas Negeri Jakarta under the contract number 25/KOMP-UNJ/LPPM/V/2020. Our simulations developed in the Digital Laboratory - Physics Education Department, Universitas Negeri Jakarta.

Data availability The authors confirm that the data supporting the findings of this study are available within the article. Raw data were generated at Learning Media Laboratory. Derived data supporting the findings of this study are available from the corresponding author Dewi Muliyati on request.

Code availability All code for data cleaning and analysis associated with the current submission is available at https://osf.io/5qwkb/. Any updates will also be published on Center of Open Science.

\section{Declarations}

\section{Ethics approval}

All participants in the research were purely voluntary and understood the process in which they were to be engaged. The participants' data were anonymized and kept confidential in the research.

All quantitative data sets of this research, which are anonymized, can be made available by individual application directly to the authors. The applicant should clearly describe where and how they will use the data sets in their contact letter. The applicant should also cite the source of the data sets in their ongoing papers. As an expert scientist and along with co-authors of the concerned field, the paper has been submitted with full responsibility, following the due ethical procedure, and there is no duplicate publication, fraud, plagiarism, or concerns about animal or human experimentation.

Consent to participate No clinical investigation is carried out on humans and animals.

Consent for publication Not applicable.

Conflicts of interest/competing interests The authors declare no conflict of interest, financial or otherwise.

\section{References}

Angeli, C., \& Giannakos, M. (2020). Computers in human behavior computational thinking education : Issues and challenges. Computers in Human Behavior journal, 105, 106185. https://doi. org/10.1016/j.chb.2019.106185

Angeli, C., \& Valanides, N. (2020). Developing young children's computational thinking with educational robotics: An interaction effect between gender and scaffolding strategy. Computers in Human Behavior, 105, 105954. https://doi.org/10.1016/j.chb.2019.03.018

Astra, I. M., Raihanati, R., \& Mujayanah, N. (2020). Development of electronic module using creative problem-solving model equipped with HOTS problems on the kinetic theory of gases material. Jurnal Penelitian \& Pengembangan Pendidikan Fisika, 6(2), 181-194. https://doi.org/10. 21009/1.06205

Atmatzidou, S., \& Demetriadis, S. (2016). Advancing students' computational thinking skills through educational robotics : A study on age and gender relevant differences. Robotics and Autonomous Systems, 75, 661-670. https://doi.org/10.1016/j.robot.2015.10.008

Bahrami, M., \& Bahrami, M. (2012). A review of software architecture for collaborative software 's. Advanced Materials Research, 440, 2372-2376. https://doi.org/10.4028/www.scientific.net/ AMR.433-440.2372

Bakri, F., Permana, H., Wulandari, S., \& Muliyati, D. (2020). Student worksheet with ar videos: Physics learning media in laboratory for senior high school students. Journal of Technology and Science Education, 10(2), 231-240. https://doi.org/10.3926/JOTSE.891

Bakri, F., Sumardani, D., \& Muliyati, D. (2019a). The 3D simulation of Lorentz force based on augmented reality technology. In journal of physics: Conference series (Vol. 1402, p. 66038). IOP publishing. https://doi.org/10.1088/1742-6596/1402/6/066038 
Bakri, F., Sumardani, D., \& Muliyati, D. (2019b). The augmented reality application for simulating electromotive force concept. Journal of Physics: Conference Series, 1402(6), 66039. https://doi.org/10. 1088/1742-6596/1402/6/066039

Bakri, F., Sumardani, D., \& Muliyati, D. (2019c). Integrating augmented reality into worksheets: Unveil learning to support higher-order thinking skills. AIP Conference Proceedings, 2169, 020012. https:// doi.org/10.1063/1.5132647

Bakri, F., Sunaryo, S., Irawan, V. F., \& Muliyati, D. (2018). E-learning model for problem based learning on heat and thermodynamic topics in high school. Jurnal Penelitian \& Pengembangan Pendidikan Fisika, 4(2), 101-112. https://doi.org/10.21009/1.04207

Barr, V., \& Stephenson, C. (2011). Computational thinking to K-12: What is involved and what is the role of the computer science education community? ACM Inroads, 2(1), 48-54. https://doi.org/10.1145/ 1929887.1929905

Basu, S., Biswas, G., \& Kinnebrew, J. S. (2017). Learner modeling for adaptive scaffolding in a computational thinking-based science learning environment. User Modeling and User-Adapted Interaction, 27(1), 5-53. https://doi.org/10.1007/s11257-017-9187-0

Bers, M. U., Flannery, L., Kazakoff, E. R., \& Sullivan, A. (2014). Computational thinking and tinkering : Exploration of an early childhood robotics curriculum. Computers \& Education, 72, 145-157. https://doi.org/10.1016/j.compedu.2013.10.020

Borinskaya, S., Kang, N., Irish, T. E., Mulder, G., Bordeianu, C. C., Panoff, R. M., et al. (2013). Instances: Incorporating computational scientific thinking advances into Education \& Science Courses. Biophysical Journal, 104(2), 532. https://doi.org/10.1016/j.bpj.2012.11.2942

Borrego, C., Fernández, C., Blanes, I., \& Robles, S. (2017). Room escape at class: Escape games activities to facilitate the motivation and learning in computer science. Journal of Technology and Science Education, 7(2), 162-171. https://doi.org/10.3926/jotse.247

Branch, R. M. (2010). Instructional design: The ADDIE approach. Springer. https://doi.org/10.1007/ 978-0-387-09506-6

Budi, A., \& Muliyati, D. (2018). Discovering and understanding the vector field using simulation in android app. Journal of Physics: Conference Series, 1013, 012062

Chalmers, C. (2018). Robotics and computational thinking in primary school. International Journal of Child-Computer Interaction, 17, 93-100. https://doi.org/10.1016/j.ijcci.2018.06.005

Chen, F. S., Ke, H. S., \& Chen, Y. C. (2020). Online learning as a panacea?: An empirical study to discuss problem-based cooperative learning in Taiwan. International Journal of Emerging Technologies in Learning, 15(18), 251-259. https://doi.org/10.3991/ijet.v15i18.15079

Chen, G., Shen, J., Barth-cohen, L., Jiang, S., Huang, X., \& Eltoukhy, M. (2017). Assessing elementary students' computational thinking in everyday reasoning and robotics programming. Computers \& education, 109, 162-175. https://doi.org/10.1016/j.compedu.2017.03.001

Chen, W., Looi, C., \& Tan, S. (2010). What do students do in a F2F CSCL classroom? The optimization of multiple communications modes. Computers \& Education, 55(3), 1159-1170. https://doi.org/10. 1016/j.compedu.2010.05.013

da Silva, A. C., Bernardes, A., Evora, Y. D. M., Dalri, M. C. B., Silva, A. R. D., \& Sampaio, C. S. J. C. (2016). Development of a virtual learning environment for cardiorespiratory arrest training. Revista da Escola de Enfermagem, 50(6), 988-995. https://doi.org/10.1590/S0080-623420160000700016

Davis, A. L. (2013). Using instructional design principles to develop effective information literacy instruction: The ADDIE model. College and Research Libraries News, 74(4), 205-207. https://doi. org/10.5860/crln.74.4.8934

Denny, Y. R., Utami, I. S., Rohanah, S., \& Muliyati, D. (2020). The development of blended learning model using Edmodo to train student critical thinking skills on impulse-momentum topic. Jurnal Penelitian \& Pengembangan Pendidikan Fisika, 6(1), 113-120. https://doi.org/10.21009/1.06113

Dinica, M., Dinescu, L., \& Miron, C. (2010). Developing the students' creative potential by using visual methods while studying physics. Procedia - Social and Behavioral Sciences, 2(2), 3731-3736. https://doi.org/10.1016/j.sbspro.2010.03.580

Fraser, D. M., Pillay, R., Tjatindi, L., \& Case, J. M. (2007). Enhancing the learning of fluid mechanics using computer simulations. Journal of Engineering Education, 96(4), 381-388. https://doi.org/10. 1002/j.2168-9830.2007.tb00946.x

Gani, A., Safitri, R., \& Mahyana, M. (2017). Improving the visual-spatial intelligence and results of learning of juniour high school students' with multiple intelligences-based students worksheet learning on lens materials. Jurnal Pendidikan IPA Indonesia, 6(1), 16-22. https://doi.org/10.15294/jpii. v6i1.9594 
Gennari, R., Fatto, V. Del, Gashi, E., Sanin, J., \& Ventura, A. (2016). Gamified technology probes for scaffolding computational thinking. COOP 2016: Proceedings of the 12th international conference on the Design of Cooperative Systems, 303-307. https://doi.org/10.1007/978-3-319-33464-6_19

Grover, S., \& Pea, R. (2013). Computational thinking in K-12: A review of the state of the field. Educational Researcher, 42(1), 38-43. https://doi.org/10.3102/0013189X12463051

Guggemos, J. (2020). On the predictors of computational thinking and its growth at the high-school level. Computers \& Education, 161, 104060. https://doi.org/10.1016/j.compedu.2020.104060

Harangus, K., \& Kátai, Z. (2020). Computational thinking in secondary and higher education. Procedia Manufacturing, 46, 615-622. https://doi.org/10.1016/j.promfg.2020.03.088

Hsu, T., Chang, S., \& Hung, Y. (2018). How to learn and how to teach computational thinking : Suggestions based on a review of the literature. Computers \& Education, 126, 296-310. https://doi.org/10. 1016/j.compedu.2018.07.004

Huang, H., Wu, C., \& Chen, N. (2012). The effectiveness of using procedural scaffoldings in a paperplus-smartphone collaborative learning context. Computers \& Education, 59(2), 250-259. https:// doi.org/10.1016/j.compedu.2012.01.015

Hubalovsky, S. (2015). Processing of experimental data as educational method of development of algorithmic thinking. Procedia - Social and Behavioral Sciences, 191, 1876-1880. https://doi.org/10. 1016/j.sbspro.2015.04.309

Hussey, T., \& Smith, P. (2010). The uses of learning outcomes. Teaching in Higher Education, 8(3), 357-368. https://doi.org/10.1080/13562510309399

Hussin, W. N. T. W., Harun, J., \& Shukor, N. A. (2019). Online interaction in social learning environment towards critical thinking skill: A framework. Journal of Technology and Science Education, 9(1), 4-12. https://doi.org/10.3926/jotse.544

Ivone, F. M., Jacobs, G. M., \& Renandya, W. A. (2020). Far apart, yet close together: Cooperative learning in online education. Studies in English language and education, 7(2), 271-289. https://doi.org/ $10.24815 /$ siele.v7i2.17285

Khasanah, A. N., Sajidan, S., \& Widoretno, S. (2017). Effectiveness of critical thinking indicator-based module in empowering student's learning outcome in respiratory system study material. Jurnal Pendidikan IPA Indonesia, 6(1), 187-195. https://doi.org/10.15294/jpii.v6i1.8490

Kim, M. C., \& Hanna, M. J. (2011). Scaffolding problem solving in technology-enhanced learning environments ( TELEs ): Bridging research and theory with practice. Computers \& Education, 56, 403417. https://doi.org/10.1016/j.compedu.2010.08.024

Kim, Y., \& Kim, J. (2016). Application of a software education program developed to improve computational thinking in elementary school girls. Indian journal of science and technology, 9(44), 1-9. https://doi.org/10.17485/ijst/2016/v9i44/105102

Kong, C. S., \& Wang, Y. Q. (2020). Formation of computational identity through computational thinking perspectives development in programming learning : A mediation analysis among primary school students. Computers in Human Behavior, 106, 106230. https://doi.org/10.1016/j.chb.2019.106230

Kong, S., Lai, M., \& Sun, D. (2020). Teacher development in computational thinking: Design and learning outcomes of programming concepts, practices and pedagogy. Computers \& Education, 151, 103872. https://doi.org/10.1016/j.compedu.2020.103872

Korkmaz, Ö., Çakir, R., \& Özden, M. Y. (2017). A validity and reliability study of the computational thinking scales (CTS). Computers in Human Behavior, 72, 558-569. https://doi.org/10.1016/j.chb. 2017.01.005

Landau, R. H., Paez, M. J., Bordeianu, C., \& Haerer, S. (2011). Making physics education more relevant and accessible via computation and eTextBooks. Computer Physics Communications, 182(9), 2071-2075. https://doi.org/10.1016/j.cpc.2010.11.006

Lei, H., Ming, M., Li, F., Wang, X., \& Geng, Y. (2020). Children and youth services review computational thinking and academic achievement : A meta-analysis among students. Children and Youth Services Review, 118, 105439. https://doi.org/10.1016/j.childyouth.2020.105439

Lin, S., Chien, S., Hsiao, C., Hsia, C., \& Chao, K. (2020). Enhancing computational thinking capability of preschool children by game-based smart toys. Electronic Commerce Research and Applications, 44, 101011. https://doi.org/10.1016/j.elerap.2020.101011

Lye, S. Y., Hwee, J., \& Koh, L. (2014). Review on teaching and learning of computational thinking through programming : What is next for K-12? Computers in Human Behavior, 41, 51-61. https://doi.org/10.1016/j.chb.2014.09.012 
Mahtari, S., Wati, M., Hartini, S., Misbah, M., \& Dewantara, D. (2020). The effectiveness of the student worksheet with PhET simulation used scaffolding question prompt. Journal of Physics: Conference Series, 1422, 012010. https://doi.org/10.1088/1742-6596/1422/1/012010

Majid, N. A. A., Mohammed, H., \& Sulaiman, R. (2015). Students' perception of Mobile augmented reality applications in learning computer organization. Procedia - Social and Behavioral Sciences, 176, 111-116. https://doi.org/10.1016/j.sbspro.2015.01.450

Malkawi, E., Alhadrami, S., \& Aljabri, A. (2019). Building an interactive Mobile application to enhance students' problem solving skills in higher education physics. In Proceedings of the 11th international conference on computer supported education (pp. 550-555). https://doi.org/10. 5220/0007780105500555

Manson, J. R., \& Olsen, R. J. (2012). Assessing and refining an undergraduate computational science curriculum. Procedia Computer Science, 1, 857-865. https://doi.org/10.1016/j.procs.2010. 04.094

Matuttis, H. (1998). Simulation of the pressure distribution under a two-dimensional heap of polygonal particles. Granular Matter, 1(2), 83-91. https://doi.org/10.1007/s100350050013

Muliyati, D., Firdaus, B., Ambarwulan, D., Fitriani, E., Siswoyo, B., \& F., \& Permana, H. (2018). Simulation of granular in two dimensions: The effect of particle velocity on rigid wall boundary. MATEC Web of Conferences, 197, 02001. https://doi.org/10.1051/matecconf/201819702001

Muliyati, D., Sumardani, D., Ambarwulan, D., Siswoyo, S., Handoko, E., Fitriani, E., \& Viridi, S. (2019). The 3-D visualization of the granular particle on various diameter porous surfaces. In Journal of Physics: Conference Series, 1402. https://doi.org/10.1088/1742-6596/1402/7/077026

Mustami, M. K., Syamsudduha, S., \& Safei, \& Ismail, M. I. (2019). Validity, practicality, and effectiveness development of biology textbooks integrated with augmented reality on high school students. International Journal of Technology Enhanced Learning, 11(2), 187-200. https://doi.org/ 10.1504/IJTEL.2019.098789

Ngan, S., \& Law, K. M. Y. (2014). Exploratory network analysis of learning motivation factors in e-learning facilitated computer programming courses. The Asia-Pacific Education Researcher, 24, 705-717. https://doi.org/10.1007/s40299-014-0223-0

Oktasari, D., Jumadi, W., Hariadi, M. H., \& Syari, E. L. (2019). 3D Page-Flipped Worksheet on Impulse-Momentum To Develop Students' Scientific Communication Skills. Jurnal Pendidikan IPA Indonesia, 8(2), 211-219. https://doi.org/10.15294/jpii.v8i2.15737

Pitkänen, K., Iwata, M., \& Laru, J. (2020). Exploring technology-oriented fab lab facilitators' role as educators in K-12 education: Focus on scaffolding novice students' learning in digital fabrication activities. International Journal of Child-Computer Interaction, 26, 100207. https://doi.org/10. 1016/j.ijcci.2020.100207

Prosperetti, A., \& Tryggvason, G. (2003). Appendix 3: Report of study group on computational physics. International Journal of Multiphase Flow, 29, 1089-1099. https://doi.org/10.1016/S03019322(03)00081-8

Psycharis, S. (2011). The computational experiment and its effects on approach to learning and beliefs on physics. Computers \& Education, 56, 547-555. https://doi.org/10.1016/j.compedu.2010.09. 011

Raihanati, R., Fitri, U. R., \& Fajrin, M. (2017). Integrated course for improve student competencies on school physics laboratory management. Jurnal Penelitian \& Pengembangan Pendidikan Fisika, 3(1), 89-96. https://doi.org/10.21009/1.03112

Redish, E. F., \& Wilson, J. M. (1993). Student programming in the introductory physics course: MUPPET. American Journal of Physics, 61, 222. https://doi.org/10.1119/1.17295

Rodriguez, B., Kennicutt, S., Rader, C., \& Camp, T. (2017). Assessing computational thinking in CS unplugged activities. Proceedings of the 2017 ACM SIGCSE technical symposium on computer science education, 501-506

Sánchez-carmona, A., Robles, S., \& Pons, J. (2017). A Gamification experience to improve engineering students' performance through motivation. Journal of Technology and Science Education, 7(2), $150-161$ 
Shah, A., Suhailiezana, K. C. G. C., \& Khairudin, M. (2019). Effectiveness of m-learning applications for design and technology subject. International Journal of Interactive Mobile Technologies, 13(10), 120-133. https://doi.org/10.3991/ijim.v13i10.11324

Sulisworo, D., Ishafit, \& Firdausy, K. (2016). The development of mobile learning application using jigsaw technique. International Journal of Interactive Mobile Technologies, 10(3), 11-16. https://doi. org/10.3991/ijim.v10i3.5268

Tang, X., Yin, Y., Lin, Q., Hadad, R., \& Zhai, X. (2020). Assessing computational thinking: A systematic review of empirical studies. Computers \& Education, 148, 103798. https://doi.org/10.1016/j.compe du.2019.103798

Taub, R., Armoni, M., Bagno, E., \& Ben-ari, M. (2015). The effect of computer science on physics learning in a computational science environment. Computers \& Education, 87, 10-23. https://doi.org/10. 1016/j.compedu.2015.03.013

Touretzky, D. S., Marghitu, D., Ludi, S., Bernstein, D., \& Ni, L. (2013). Accelerating K-12 computational thinking using scaffolding, staging, and abstraction. Proceeding of the 44th ACM technical symposium on computer science education, 609-614

Tumanggor, A. M., Jumadi, J., Wilujeng, I., \& Ringo, E. S. (2019). The profile of students' physics problem solving ability in optical instruments. Jurnal Penelitian \& Pengembangan Pendidikan Fisika, 5(1), 29-40. https://doi.org/10.21009/1.05104

Voogt, J., Fisser, P., Good, J., Mishra, P., \& Yadav, A. (2015). Computational thinking in compulsory education: Towards an agenda for research and practice. Education and Information Technologies, 20, 715-728. https://doi.org/10.1007/s10639-015-9412-6

Waiyakoon, S., Khlaisang, J., \& Koraneekij, P. (2015). Development of an instructional learning object design model for tablets using game-based learning with scaffolding to enhance mathematical concepts for mathematic learning disability students. Procedia - Social and Behavioral Sciences, 174, 1489-1496. https://doi.org/10.1016/j.sbspro.2015.01.779

Wing, J. M. (2006). Computational thinking. Communication of The ACM, 49(3), 33-35. https://doi.org/ $10.1145 / 1118178.1118215$

Wood, D., Bruner, J. S., \& Ross, G. (1976). The role of tutoring in problem solving. Journal of Child Psychology and Psychiatry, 17, 89-100. https://doi.org/10.1111/j.1469-7610.1976.tb00381.x

Yao, Y. (2016). Granular Computing : Past, Present and Future. RSKT 2008: Rough Sets and Knowledge Technology, 5009, 27-28. https://doi.org/10.1007/978-3-540-79721-0

Ye, M., Jiang, X., Li, S., \& Wang, L. (2021). Large-scale first-principles quantum transport simulations using plane wave basis set on high performance computing platforms. Computer Physics Communications, 260, 107737. https://doi.org/10.1016/j.cpc.2020.107737

Yulkifli, Y., Ningrum, M. V., \& Indrasari, W. (2019). The validity of student worksheet using inquirybased learning model with science process skill approach for physics learning of high school. Jurnal Penelitian \& Pengembangan Pendidikan Fisika, 5(2), 155-162. https://doi.org/10.21009/1.05210

Zhang, L., \& Nouri, J. (2019). A systematic review of learning computational thinking through scratch in K-9. Computers \& Education, 141, 103607. https://doi.org/10.1016/j.compedu.2019.103607

Publisher's note Springer Nature remains neutral with regard to jurisdictional claims in published maps and institutional affiliations. 


\section{Authors and Affiliations}

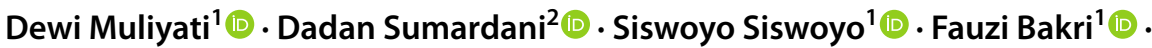

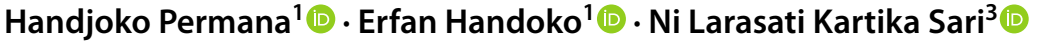

Dadan Sumardani

s1090815@mail.ncyu.edu.tw

Siswoyo Siswoyo

siswoyo@unj.ac.id

Fauzi Bakri

fauzi-bakri@unj.ac.id

Handjoko Permana

handjoko@unj.ac.id

Erfan Handoko

erfan@unj.ac.id

Ni Larasati Kartika Sari

nilarasati@civitas.unas.ac.id

1 Physics Education Department, Universitas Negeri Jakarta, Jakarta, Indonesia

2 Teachers College, National Chiayi University, Chiayi City, Taiwan

3 Physics Department, Universitas Nasional, Jakarta, Indonesia 